\title{
Pathologic Mutagenesis
}

National Cancer Institute

\section{Source}

National Cancer Institute. Pathologic Mutagenesis. NCI Thesaurus. Code C19154.

Any event, process, or activity that produces a deleterious alteration of DNA. (NCI) 